\title{
The preconscious mind and gamma band activity in the reticular activating system
}

\section{Subimal Datta ${ }^{1,2 *}$ \\ Department of Psychiatry, Boston University School of Medicine, Boston, MA, USA \\ 2 Department of Neurology, Boston University School of Medicine, Boston, MA, USA \\ *Correspondence: subimal@bu.edu}

\section{A commentary on}

Gamma band activity in the reticular activating system (RAS)

by Urbano, F. J., Kezunovic, N., Hyde, J. R., Dana Simon, C., Beck, P. B., and Garcia-Rill, E. (2012). Front. Neur. 3:6. doi: 10.3389/ fneur.2012.00006.

Gamma waves are high frequency neural oscillations in the range of $30-100 \mathrm{~Hz}$, on average $\sim 40 \mathrm{~Hz}$. These waves have been implicated in creating the unity of conscious perception, or binding, and are related to awareness, problem solving, and rapid eye movement (REM) sleep. Based on our level of awareness, Sigmund Freud and his followers have divided the mind into three different parts, the preconscious mind, the subconscious mind, and the conscious mind. The preconscious mind includes those things of which we are aware, but to which we are not paying attention. If we choose to pay attention, we bring them to the conscious mind (Civin and Lombardi, 1990). In this issue of Frontiers in Sleep and Chronobiology, Urbano et al. (2012) suggest that gamma band activity in the reticular activating system (RAS) mediates preconscious awareness, and that it is the maintained high frequency activity across various nuclei that keeps the "stream of consciousness," as William James called it, flowing across our preconscious mind (James, 2007). This mechanism allows us to survive in a complex world, being aware of the traffic and pedestrians around us as we commute to work. When a stimulus introduces potential danger, for example, an oncoming bus, we instantly bring it into conscious control in order to respond.

This review article is a collaboration between Dr. Edgar Garcia-Rill's lab at the Center for Translational Neuroscience at the University of Arkansas for Medical Sciences and the lab of Dr. Francisco Urbano at the University of Buenos Aires, Argentina. They refer to a series of recent articles published in excellent journals that convincingly demonstrate the presence of gamma band activity in cells of the pedunculopontine tegmental nucleus (PPT), the intralaminar thalamic parafascicular nucleus (Pf), and the pontine subcoeruleus nucleus dorsalis (SubCD; Simon et al., 2010, 2011; Kezunovic et al., 2011, 2012). The PPT is involved in the modulation of waking and REM sleep, while the Pf can affect cortical arousal, and the SubCD controls phasic pontine-wave (P-wave) activity of REM sleep - all states marked by high frequency activity (Datta, 2010). Using an in vitro technique, Garcia-Rill's group found high threshold calcium channels in every PPT and Pf cell, and activation of these channels drives the cells to fire faster and faster, until they plateau at gamma band frequencies. The cells simply reach a point at which they do not fire any faster, which is not the case in many CNS regions. In addition, every SubCD cell studied exhibited sodiumdependent sub-threshold oscillations that maintained firing in the beta/gamma range. Classic in vivo studies by Mircea Steriade had established that cells in the PPT and intralaminar thalamus could fire in the gamma band range (Steriade et al., 1990, 1991, 1993), and NMDA receptor-mediated activation of PPT cells has been shown to induce gamma wave activity in the cerebral cortex (Datta et al., 2001), but the cellular mechanisms had not yet been identified.

The key to manifesting gamma band activity in vitro is that these observations in Garcia-Rill's laboratory used recordings at close to body temperature $\left(\sim 37^{\circ} \mathrm{C}\right)$, as opposed to the usual slice work that is conducted at $30^{\circ} \mathrm{C}$. Under such conditions, there is a flourish of high frequency activity in these key RAS nuclei, and we are then inspired to ask, what is the function of this high frequency activity? It is assumed that the flow of information from the sensory systems that is sent in parallel to the RAS provides the continuous information that maintains such activity. These authors conclude that the most parsimonious explanation for their observations is that this mechanism participates in the process of preconscious awareness. Future studies will need to demonstrate that this is indeed the function of this mechanism, but already we have some indications that this might be the case. For example, knockout mice without these calcium channels show very low gamma band activity, have sleep dysregulation, motor problems, and die (usually of low frequency seizures) by 3 weeks of age (Llinás et al., 2007). However, there is still much information needed before behavioral studies can be performed to demonstrate this function, for example knowledge about the other channels involved, how this mechanism is modulated by local transmitter systems, and how it is affected during development.

This review (Urbano et al., 2012) takes us on a ride through the literature, reminding us of the considerable work it has taken to piece together the cellular mechanisms involved in generating gamma band activity in the cortex, and introducing us to new work that documents the presence of gamma waves in the hippocampus and cerebellum. Given this background, it is not surprising to find gamma band activity in the RAS. The authors call the RAS a "gamma making machine" and explain a concept that few of us realize: in order to maintain a circuit firing at gamma band frequencies $(\sim 40 \mathrm{~Hz})$, synaptic interactions by themselves cannot maintain the rhythm due to the likely failure of multiple synapses at such high frequencies. That is, it is probably the presence of both synaptic interactions and intrinsic membrane properties (e.g., sub-threshold oscillations) that enable the maintenance of such fast activity. The discovery of these mechanisms behind gamma band activity, therefore, is critical to understanding the function of the RAS. 
As indicated in a recent study, one of the mechanisms for gamma band activity could be the activation of intracellular CaMKII within the PPT (Datta et al., 2011). In addition, a complete understanding of the mechanisms behind gamma band activity in the RAS should allow the development of novel stimulants and anesthetics, as well as agents that modulate awareness. The implications of this work are profound, and we should pay conscious attention to these findings and their relevance to the preconscious mind.

\section{REFERENCES}

Civin, M., and Lombardi, K. L. (1990). The preconscious and potential space. Psychoanal. Rev. 77, 573-585.

Datta, S. (2010). Cellular and chemical neuroscience of mammalian sleep. Sleep Med. 11, 431-440.

Datta, S., O'Malley, M. W., and Patterson, E. H. (2011). Calcium/calmodulin kinase II in the pedunculopontine tegmental nucleus modulates the initiation and maintenance of wakefulness. J. Neurosci. 31, $17007-17016$.

Datta, S., Patterson, E. H., and Spoley, E. E. (2001). Excitation of the pedunculopontine tegmental
NMDA receptors induces wakefulness and cortical activation in the rat. J. Neurosci. Res. 66, 109-116.

James, W. (2007). The Principles of Psychology. New York: Cosimo Classics.

Kezunovic, N., Hyde, J., Simon, C., Urbano, F. J., and Garcia-Rill, E. (2012). Gamma band activity in the developing parafascicular nucleus (Pf). $J$. Neurophysiol. 107, 772-784.

Kezunovic, N., Urbano, F. J., Simon, C., Hyde, J., Smith, K., and Garcia-Rill, E. (2011). Mechanism behind gamma band activity in the pedunculopontine nucleus (PPN). Eur. J. Neurosci. 34, 404-415.

Llinás, R. R., Choi, S., Urbano, F. J., and Shin, H. S. (2007). Gamma-band deficiency and abnormal thalamocortical activity in P/Q-type channel mutant mice. Proc. Natl. Acad. Sci. U.S.A. 104, 17819-17824.

Simon, C., Kezunovic, N., Williams, D. K., Urbano, F. J., and Garcia-Rill, E. (2011). Cholinergic and glutamatergic agonists induce gamma frequency activity in dorsal subcoeruleus nucleus neurons. Am. J. Physiol. 301, C327-C335.

Simon, C., Kezunovic, N., Ye, M., Hyde, J., Hayar, A., Williams, D. K., and Garcia-Rill, E. (2010). Gamma band unit and population responses in the pedunculopontine nucleus. J. Neurophysiol. 104, 463-474.

Steriade, M., Curro Dossi, R., Paré, D., and Oakson, G. (1991). Fast oscillations $(20-40 \mathrm{~Hz})$ in thalamocortical systems and their potentiation by mesopontine cho- linergic nuclei in the cat. Proc. Nat. Acad. Sci. U.S.A. $88,4396-4400$.

Steriade, M., Curro-Dossi, R., and Contreras, D. (1993). Electrophysiological properties of intralaminar thalamocortical cells discharging rhythmic $(\sim 40 \mathrm{~Hz})$ spike-bursts at $\sim 1000 \mathrm{~Hz}$ during waking and rapid eye movement sleep. Neuroscience 56, 1-9.

Steriade, M., Datta, S., Paré, D., Oakson, G., and Curro Dossi, R. (1990). Neuronal activities in brainstem cholinergic nuclei related to tonic activation processes in thalamocortical systems. J. Neurosci. 10, 2541-2559.

Urbano, F. J., Kezunovic, N., Hyde, J. R., Dana Simon, C., Beck, P. B., and Garcia-Rill, E. (2012). Gamma band activity in the reticular activating system (RAS). Front Neurol. 3:6. doi: 10.3389/fneur.2012.00006.

Received: 23 January 2012; accepted: 25 January 2012; published online: 08 February 2012.

Citation: Datta S (2012) The preconscious mind and gamma band activity in the reticular activating system. Front. Neur. 3:16. doi: 10.3389/fneur.2012.00016

This article was submitted to Frontiers in Sleep and Chronobiology, a specialty of Frontiers in Neurology.

Copyright $\odot 2012$ Datta. This is an open-access article distributed under the terms of the Creative Commons Attribution Non Commercial License, which permits non-commercial use, distribution, and reproduction in other forums, provided the original authors and source are credited. 